\title{
Komposisi Nutrisi dan Kecernaan Silase Jerami Jagung yang Ditambah Lamtoro dan Molases yang Difermentasi pada Waktu Berbeda
}

\section{(Nutrition Composition and Digestibility of Corn Straw Silage Added Leucaena and Molasses Fermented at Different Times)}

\author{
Oscar Yanuarianto, Muhamad Amin, Sofyan Damrah Hasan, Syamsul Hidayat Dilaga, Suhubdy \\ Laboratorium Ilmu Nutrisi dan Makanan Ternak Ruminansia/Herbivora \\ Fakultas Peternakan Universitas Mataram \\ Jl. Majapahit 62 Mataram 83125 NTB. Telpon (0370)633603; Fax (0370) 640592 \\ E-mail : oscary338@gmail.com
}

Diterima : 15 Maret 2020/Disetujui : 17 Mei 2020

\begin{abstract}
ABSTRAK
Penelitian yang bertujuan untuk mengetahui kandungan protein kasar (PK), serat kasar (SK) dan kecernaan in vitro bahan kering $(\mathrm{KcBK})$ dan bahan organik $(\mathrm{KcBO})$ silase jerami jagung yang ditambahkan lamtoro dan molase yang difermentasi pada waktu yang berbeda, telah dilakukan di Laboratorium Nutrisi dan Makanan, Fakultas Peternakan, Universitas Mataram. Jerami jagung dan lamtoro yang digunakan dalam penelitian ini diperoleh dari area pertanian di sekitar Kecamatan Gerung, Kabupaten Lombok Barat, yang diambil segera setelah panen dan dipotong-potong dengan ukuran 3-5 cm. Penelitian ini menggunakan Rancangan Acak Lengkap (RAL) yang terdiri dari 5 level perlakuan, yaitu: T1: jerami jagung + leucaena 10\% dan molase 5\% tanpa fermentasi, T2: jerami jagung + leucaena 10\% dan molases 5\% difermentasi 7 hari, T3: jerami jagung + leucaena $10 \%$ dan molases 5\% difermentasi 14 hari, T4: jerami jagung + leucaena 10\% dan molases 5\% difermentasi 21 hari, T5: jerami jagung + leucaena $10 \%$ dan molase 5\% difermentasi 28 hari. Variabel yang diamati dalam penelitian ini adalah PK, SK, dan kecernaan Bahan Kering (KcBK) dan KcBO secara in vitro. Data yang diperoleh dalam penelitian ini dianalisis menggunakan analisis variansi berdasarkan Rancangan Acak Lengkap menggunakan paket program statistik SAS dan perbedaan selanjutnya diuji menggunakan Uji Duncan. Hasil penelitian menunjukkan bahwa waktu fermentasi dapat secara signifikan mengurangi (P $<0,05)$ kandungan SK dan meningkatkan $(\mathrm{P}<0,05)$ kandungan $\mathrm{PK}$ silase, tetapi tidak ada peningkatan yang signifikan $(\mathrm{P}>0,05) \mathrm{KcBK}$ dan $\mathrm{KcBO}$ silase yang difermentasi selama 7, 14, 21 dan 28 hari.
\end{abstract}

Kata kunci: jerami jagung, silase, nutrisi, kecernaan, waktu

\begin{abstract}
The study that aimed to determine the content of crude protein $(\mathrm{CP})$, crude fiber (CF) and in vitro digestibility of dry matter $(\mathrm{DM})$ and organic matter $(\mathrm{OM})$ of corn straw silage added with leucaena and molasses fermented at different times, had been carried out at Nutrition and Feed Laboratory, Faculty of Animal Husbandry, University of Mataram. The corn straw and leucana used in this study were taken from the agricultural area in the Gerung sub-district of West Lombok Regency shortly after harvesting and were cut into pieces with a size of 3-5 cm. This study used a Completely Randomized Design (CRD) consisting of 5 level of treatments, namely: T1: corn straw + leucaena 10\% and molasses $5 \%$ without fermentation, T2: corn straw + leucaena $10 \%$ and molasses $5 \%$ fermented 7 days, T3: corn straw + leucaena $10 \%$ and molasses $5 \%$ fermented 14 days, T4: corn straw + leucaena $10 \%$ and molasses $5 \%$ fermented 21 days, T5: corn straw + leucaena $10 \%$ and molasses $10 \%$ fermented 28 days. The variables observed in this study were CP, CF, and in vitro digestibility of DM and OM. Data obtained in this study were analyzed using analysis of variance based on a Completely Randomized Design using the SAS statistical program package and the differences were further tested using the Duncan Test. The results showed that fermentation time could significantly decrease $(\mathrm{P}<0.05) \mathrm{CF}$ content and increase $(\mathrm{P}<0.05)$ $\mathrm{CP}$ silage content, but there was no significant increase $(\mathrm{P}>0.05)$ of $\mathrm{DM}$ and $\mathrm{OM}$ digestibility in vitro of silage fermented for 7, 14, 21 and 28 days.
\end{abstract}

Keywords: corn straw, silage, nutrition, digestibility, time. 


\section{PENDAHULUAN}

Ketersediaan pakan merupakan kendala utama yang sering dihadapi oleh peternak sapi dan kerbau pada umumnya, hal ini sangat dirasakan oleh peternak terutama pada musim kemarau, ketersediaan hijauan segar yang berkualitas sangat berkurang berbanding terbalik dengan ketersediaannya pada musim hujan. Ketersediaan pakan ini juga semakin diperparah dengan semakin menyempitnya areal penggembalaan ternak, sawah dan kebun, di samping itu dengan besarnya pembangunan, lahan padang rumput alam tersebut makin berkurang. Untuk mengantisipasi kendala ketersediaan pakan yang berfluktuatif tersebut perlu dilakukan usaha-usaha penerapan sistem pengaturan, penyimpanan dan pengawetan hijauan secara baik. Usaha-usaha ini perlu dilakukan terutama pada musim hujan dimana produksi cukup banyak sehingga hijauan awetan dapat digunakan untuk mengatasi kekurangan hijauan segar pada musim kering.

\section{Pemanfaatan limbah pertanian} seperti jerami jagung merupakan salah satu usaha untuk mengatasi masalah kekurangan pakan ternak di musim kemarau. Jerami jagung merupakan hasil ikutan bertanam jagung dengan tingkat produksi mencapai 4-5 ton/ha. Kandungan nutrisi jerami jagung diantaranya protein kasar 4,77 \%, serat kasar 30,53\%, lemak kasar 1,06\%, abu 8,42\% dan BETN $55,82 \%$ (Nursiam, 2010). Dengan demikian, karakterisitik jerami jagung sebagai pakan ternak tergolong hijauan bermutu rendah karena memiliki kandungan serat kasar tinggi sehingga daya cernanya rendah. Kualitas jerami jagung dapat ditingkatkan dengan teknologi silase yaitu proses fermentasi yang dibantu jasad renik dalam kondisi an aerob (tanpa oksigen). Teknologi silase selain dapat mengawetkan pakan juga meningkatkan kualitas pakan.

Penambahan bahan aditif pada silase bertujuan untuk meningkatkan nilai nutrisi silase. Salah satu bahan aditif yang sering digunakan dalam pembuatan silase adalah molases. Molases merupakan hasil samping dari industri pengolahan gula dengan bentuk cair. Molases merupakan sumber energi yang potensial dari limbah pengolahan tebu dan relative harganya lebih murah disbanding sumber energi yang lain, oleh karena itu molases banyak dimanfaatkan sebagai bahan tambahan untuk pakan dengan kandungan nutrisi yang cukup baik. Kandungan nutrisi molasses terdiri dari kadar air 23\%, bahan kering $77 \%$, protein kasar 4,2\%, lemak kasar $0,2 \%$, serat kasar 7,7\%, Ca 0,84\%, P 0,09\%, BETN 57,1\%, abu 0,2\% (Sukria dan Rantan, 2009), dan energi metabolis $2.280 \mathrm{kkal} / \mathrm{kg}$ (Anggorodi,1995).

Penambahan jumlah air yang digunakan dalam pembuatan silase pada umumnya berdasarkan bahan kering bahan hal ini akan sangat sulit diterapkan dilapangan, akan lebih mudah bila menggunakan penndekatan daya ikat air pada bahan yang akan digunakan dalam proses pembuatan silase (Oscar dkk. 2016).

Lamtoro merupakan salah satu tanaman leguminosa yang sedang gencar 
gencarnya ditanam sebagai salah satu tanaman sumber ptrotein sekaligus sebagai tanaman penghijauan di Pulau Sumbawa yang mempunyai potensi sebagai pakan ternak yang cukup baik dengan kandungan protein kasar berkisar antara $27-34 \%$ (Mathius, 1984). Pemberian daun lamtoro (Leucaena leococephala) dilakukan untuk penambahan kandungan protein dalam silase, dimana daun lamtoro diharapkan dapat dipergunakan sebagai salah satu bahan untuk memperbaiki kandungan zatzat makanan, karena dapat meningkatkan kandungan nitrogen yang dapat dirombak menjadi protein mikroba. Hasil penelitian Oscar dkk. (2016), penambahan $10 \%$ daun lamtoro pada pembuatan silase jerami jagung memberikan sifat fisik dan komposisi kimia serta kecernaan yang baik.

Berdasarkan uraian di atas maka telah dilakukan penelitian untuk mengetahui pengaruh lama waktu fermentasi terhadap kandungan protein kasar, serat kasar dan kecernaan in vitro bahan kering dan bahan organik silase jerami jagung (zea mays).

\section{MATERI DAN METODE}

Penelitian ini dilaksanakan di Laboratorium Ilmu Nutrisi dan Makanan Ternak Fakultas Peternakan Universitas Mataram. Jerami jagung yang digunakan dalam penelitian ini diambil segera setelah panen, berasal dari areal persawahan di sekitar Kecamatan Gerung kabupaten Lombok Barat.

\section{Penentuan Daya ikat air}

Penentuan daya ikat air ini bertujuan untuk mengetahui jumlah larutan untuk menyemprot jerami jagung. Satu kg jerami jagung dalam kantong berlubang (1 mm) dicelupkan ke dalam air yang telah diketahui banyaknya sampai basah secara merata. Kemudian diangkat dan ditiriskan sampai airnya habis menetes. Selisih air awal dengan air yang tertinggal di dalam ember merupakan jumlah air yang mampu diikat oleh jerami jagung. Jumlah air inilah yang akan digunakan pada masing masing perlakuan.

\section{Fermentasi jerami jagung}

Jerami jagung yang digunakan dalam penelitian ini diperoleh di areal persawahan disekitar Kecamatan Gerung Kabupaten Lombok Barat merupakan jerami jagung yang baru dipanen dan dipotong-potong dengan ukuran $3-5 \mathrm{~cm}$. Penelitian dibagi dalam lima perlakuan, masing-masing perlakuan terdiri dari 5 ulangan. Adapun perlakuan tersebut adalah T1 : Jerami Jagung + Lamtoro $10 \%$ dan molases $5 \%$ tanpa fermentasi, T2: Jerami Jagung + Lamtoro $10 \%$ dan molases 5\% difermentasi 7 hari, T3: Jerami Jagung + Lamtoro $10 \%$ dan molases 5\% difermentasi 14 hari, T4 : Jerami Jagung + Lamtoro $10 \%$ dan molases 5\% difermentasi 21 hari, T5 : Jerami Jagung + Lamtoro $10 \%$ dan molases $5 \%$ difermentasi 28 hari. Persentase lamtoro dan molases yang ditambahkan dalam proses pembutan silase berdasarkan berat jerami jagung sebelum direndam air. Masing-masing perlakuan dimasukkan dalam stoples kedap udara dan difermentasikan sesuai 
dengan perlakuan. Pada akhir fermentasi, silase jerami jagung dikeluarkan dari masing-masing stoples untuk dikeringkan pada suhu $60^{\circ} \mathrm{C}$ selama $8-12$ jam, kemudian jerami digiling dan disaring dengan diameter saring $1 \mathrm{~mm}$. Sampel yang telah disaring siap untuk dianalisis di Laboratorium.

\section{Variabel yang diamati}

Variabel yang diukur dalam penelitian ini adalah kandungan protein kasar, serat kasar, kecernaan in vitro bahan kering dan bahan organik.

\section{Analisis data}

Data yang diperoleh dalam penelitian ini dianalisis dengan analisis sidik ragam atas dasar Rancangan Acak Lengkap (RAL) dengan paket program statistik SAS (2001) dan diuji lanjut dengan Uji Jarak Berganda Duncan's (Steel dan Torrie, 1989).

\section{HASIL DAN PEMBAHASAN}

\section{Protein kasar}

Rataan kandungan PK silase jerami jagung yang ditambah lamtoro dan molases pada waktu yang berbeda dapat dilihat pada Tabel 1 di bawah ini.

Tabel 1. Rataan kandungan PK dan SK silase jerami jagung yang ditambah daun lamtoro dan molases pada waktu yang berbeda

\begin{tabular}{lccccc}
\hline \hline \multirow{2}{*}{ Variabel } & \multicolumn{5}{c}{ Perlakuan } \\
\cline { 2 - 6 } & T1 & T2 & T3 & T4 & T5 \\
\hline PK (\%) & $7,51^{\mathrm{a}}$ & $9.26^{\mathrm{b}}$ & $9.97^{\mathrm{bc}}$ & $10.56^{\mathrm{d}}$ & $10.23^{\mathrm{cd}}$ \\
SK $(\%)$ & $28.85^{\mathrm{a}}$ & $29,20^{\mathrm{a}}$ & $28,50^{\mathrm{ab}}$ & $27,90^{\mathrm{b}}$ & $26,20^{\mathrm{c}}$ \\
Lignin & $10.99^{\mathrm{a}}$ & $9.08^{\mathrm{b}}$ & $7.72^{\mathrm{c}}$ & $7.34^{\mathrm{c}}$ & $6.49^{\mathrm{c}}$ \\
\hline
\end{tabular}

$\overline{\text { abcd }}$ Superskrip yang berbeda pada baris yang sama menunjukkan perbedaan sangat nyata $(\mathrm{P}<0,01)$.

Hasil analisis sidik ragam menunjukkan bahwa lama fermentasi memberikan pengaruh yang sangat nyata $(\mathrm{P}<0,01)$ terhadap peningkatan kandungan kandungan PK silase jerami jagung yang ditambah lamtoro dan molases. Uji jarak berganda Duncan's menunjukkan bahwa PK T4 nyata lebih tinggi $(\mathrm{P}<0.05)$ jika dibandingkan dengan perlakuan lainnya demikian juga perlakuan T5 jika dibandingkan dengan perlakuan $\mathrm{T} 2$ dan T1, akan tetapi tidak terdapat perbedaan yang nyata $(\mathrm{P}>0.05)$ peningkatan $\mathrm{PK}$ pada perlakuan T1 jika dibandingkan dengan T2 dan T3 demikian juga antara perlakuan T3 dan T5. Lebih tingginya kandungan PK T4 dan T5 jika dibandingkan dengan perlakuan lainnya diduga disebabkan oleh waktu fermentasi yang lebih lama sehingga menyebabkan kesempatan mikroorganisme pencerna protein bekerja merombak protein menjadi senyawa yang lebih sederhana lebih banyak sehingga jumlah mikroba yang tumbuh menjadi lebih banyak yang pada akhirnya dapat meningkatkan total protein silase yang berasal dari sumbangan protein mikroba. Pendapat ini didukung oleh Fardiaz, (1992) yang menyatakan bahwa Waktu fermentasi yang singkat mengakibatkan terbatasnya kesempatan dari mikroorganisme untuk 
terus berkembang sehingga komponen substrat yang dapat dirombak menjadi massa sel juga akan sedikit, tetapi dengan waktu yang lebih lama berarti memberi kesempatan bagi mikroorganisme untuk tumbuh dan berkembang biak Semakin lama waktu fermentasi maka semakin banyak zat makanan yang dirombak seperti bahan kering dan bahan organik termasuk di dalamnya PK sehingga total populasi mikroba menjadi lebih banayak, Total protein mikroba yang ada pada akhirnya akan menambah total protein silase yang dihasilkan.

\section{Serat Kasar}

Rataan kandungan SK silase jerami jagung yang dihasilkan tertinggi pada perlakuan $\mathrm{T} 1(28,85 \%)$ dan terendah pada perlakuan T5 (26,2\%). Hasil analisis sidik ragam menunjukkan bahwa lama pemeraman silase jerami jagung yang ditambah daun lamtoro dan molases memberikan pengaruh yang berbeda sangat nyata $(\mathrm{P}<0.01)$ terhadap kandungan SK silase jerami jagung yang dihasilkan. Hasil uji lanjut Duncan's menunjukkan bahwa kandungan SK perlakuan T5 lebih rendah dibandingkan dengan perlakuan lainnya. Rataan serat kasar secara keseluruhan mengalami penurunan sejalan dengan semakin lamanya waktu fermentasi. Waktu fermentasi yang singkat mengakibatkan terbatasnya kesempatan dari mikroorganisme untuk terus berkembang sehingga komponen substrat yang dapat dirombak menjadi massa sel juga akan sedikit, tetapi dengan waktu yang lebih lama berarti memberi kesempatan bagi mikroorganisme untuk tumbuh dan berkembang biak (Fardiaz, 1992). Semakin lama waktu fermentasi maka semakin banyak zat makanan yang dirombak seperti bahan kering dan bahan organik. Menurut Judoamidjojo et al. (1989), mikroba yang dimasukkan ke dalam medium baru, tidak akan segera tumbuh dan waktu generasinya masih lambat, hal ini tergantung spesies dan umur mikroba, substrat serta faktor lingkungan pertumbuhan. Peningkatan lama waktu fermentasi menyebabkan meningkatnya kesempatan mikroba untuk melakukan pertmbuhan dan fermentasi, sehingga semakin lama fermentasi maka kesempatan untuk mendegradasi jerami jagung semakin tinggi. Dengan demikian semakin lama fermentasi maka serat kasar jerami jagung semakin menurun.

Menurunnya kandungan SK dikarenakan oleh bakteri asam laktat yang merupakan bakteri selulolitik. Mikrobia yang bersifat selulolitik mampu menghasilkan enzim selulase yang dapat memecah selulosa sehingga akan dihasilkan glukosa (Volk dan Wheeler, 1993). Sepaham dengan Mc. Donald (1981) menjelaskan pembuatan silase dengan memanfaatkan bakteri asam laktat sebagai inokulum dapat mengikat selulose dalam pakan yang mengandung serat kasar sehingga akan menurunkan ikatan lignin dan dapat meningkatkan daya cerna.

\section{Kecernaan Bahan Kering (KcBK)}

Kecernaan merupakan perubahan fisik dan kimia yang dialami bahan pakan dalam alat pencernaan. Mikroba dalam rumen menyebabkan pakan mengalami perombakan sehingga sifat-sifat fisik 
berubah yaitu menjadi partikel kecil, dan sifat kimianya berubah secara fermentatif menjadi senyawa lain yang berbeda dengan nutrien asalnya (Sutardi, 1980).
Rataan perhitungan pengukuran kecernaan bahan kering selama penelitian dari masing-masing perlakuaan dapat dilihat pada Tabel 2.

Tabel 2. Rataan KcBK dan KcBO silase jerami jagung yang ditambah daun lamtoro dan molases pada waktu yang berbeda

\begin{tabular}{ccrrrr}
\hline \multirow{2}{*}{ Variabel } & \multicolumn{5}{c}{ Perlakuan } \\
\cline { 2 - 6 } & T1 & T2 & T3 & \multicolumn{1}{c}{ T4 } & \multicolumn{1}{c}{ T5 } \\
\hline KcBK (\%) & $47,39^{\mathrm{a}}$ & $60,15^{\mathrm{b}}$ & $60,38^{\mathrm{b}}$ & $61,20^{\mathrm{b}}$ & $61,67^{\mathrm{b}}$ \\
KcBO (\%) & $50,95^{\mathrm{a}}$ & $62,05^{\mathrm{b}}$ & $61,56^{\mathrm{b}}$ & $62,38^{\mathrm{b}}$ & $63,33^{\mathrm{b}}$ \\
\hline
\end{tabular}

${ }^{\text {ab }}$ Superskrip yang berbeda pada baris yang sama menunjukan perbedaan nyata $(\mathrm{P}<0,05)$.

Rataan kecernaan bahan kering silase jerami jagung yang ditambah daun lamtoro dan molases tertinggi diperoleh pada perlakuan T5 $(61,67 \%)$, dan terendah pada perlakuan T1 (47,39\%). Hasil analisis ragam menunjukkan bahwa lama fermentasi berpengaruh nyata $(\mathrm{P}<0,05)$ terhadap KcBK silase jerami jagung yang dihasilkan. Uji lanjut Duncan's menunjukkan bahwa KcBK pada perlakuan T1 nyata lebih rendah $(\mathrm{P}<0,05)$ jika dibandingkan dengan perlakuan lainnya, akan tetapi tidak terdapat perbedaan yang nyata $(\mathrm{P}>0.05)$ lama fermentasi terhadap $\mathrm{KcBK}$ antara perlakuan T2, T3, T4 dan T5. Lebih rendahnya KcBK perlakuan $\mathrm{T} 1$ jika dibandingkan dengan perlakuan lainnya dapat disebabkan oleh lebih tingginya kandungan SK pada perlakuan T1 yang disebabkan tidak adanya kesempatan mikroorganisme untuk merombak zat makanan menjadi senyawa yang lebih sederhana.

Daya cerna bahan pakan berhubungan erat dengan komposisi kimiawinya terutama kandungan serat kasarnya (Tillman et al., 1998). Anggorodi (1995) menambahkan bahwa semakin banyak serat kasar yang terdapat dalam suatu bahan pakan, semakin tebal dan semakin tahan dinding sel dan akibatnya semakin rendah daya cerna bahan pakan tersebut. Sebaliknya bahan pakan dengan serat kasar yang rendah pada umumnya akan lebih mudah dicerna, karena dinding sel dari bahan tersebut tipis sehingga mudah ditembus oleh getah pencernaan.

Serat kasar yang tinggi biasanya diikuti dengan kandungan lignin yang tinggi sehingga dapat menurunkan kecernaan (Tillman et al.,1998). Semakin tinggi lignin maka semakin rendah nilai kecernaanya, begitu pula sebaliknya. Hasil analisis komposisi dinding sel masing-masing perlakuan menunjukkan bahwa kandungan lignin pada T5 lebih rendah jika dibandingkan perlakuan lainnya. (Tabel.1) Jafar dan Hasan (1990) menyatakan bahwa persentase lignin dalam dinding sel mempengaruhi kecernaan pakan, semakin tinggi persentase lignin dalam dinding sel maka kecernaan pakan semakin rendah, demikian juga sebaliknya. Hal yang sama juga diperoleh pada penelitian Amrin (2014) yang menunjukkan bahwa semakin 
tinggi konsentrasi lignin dalam dinding sel tanaman maka kecernaanya semakin rendah.

Tingginya KcBK juga disebabkan karena KcBOnya juga tinggi. Hal ini sejalan dengan pendapat Reksohadiprodjo (1985) yang menyatakan bahwa meningkatnya KcBO disebabkan karena meningkatnya KcBK, sebab secara proporsional laju keluarnya bahan kering selalu diikuti oleh keluarnya bahan organik, sehingga dengan meningkatnya KcBK maka akan meningkat pula KcBO.

\section{Kecernaan Bahan Organik}

Rataan KcBO selama penelitian dari masing-masing perlakuan dapat dilihat pada Tabel 2. Rataan KcBO silase jerami jagung berturut-turut adalah $\mathrm{T} 1$ (50,95\%), T2 (62,05\%). T3 (61,56\%), T4 $(62,38 \%)$ dan T5 (63,33\%). Hasil analisis ragam menunjukkan bahwa fermentasi berpengaruh nyata $(\mathrm{P}<0,05)$ terhadap KcBO silase jerami jagung yang dihasilkan. Uji lanjut Duncan's menunjukkan bahwa KcBO perlakuan T1 nyata lebih rendah $(\mathrm{P}<0.05)$ jika dibandingkan dengan perlakuan lainnya, akan tetapi lama fermentasi antara perlakuan T2, T3, T4 dan T5 tidak meberikan pengaruh yang nyata $(\mathrm{P}>0.05)$ terhadap KcBOnya. Jika dilihat dari rerata KcBO masing-masing perlakuan, bahwa terdapat kecenderungan, semakin lama pemeraman maka semakin meningkat nilai KcBOnya. Rendahnya KcBO pada perlakuan T1 jika dibandingkan dengan perlakuan lainnya diduga disebabkan oleh tidak adanya kesempatan mikroorganisme untuk mendegradasi bahan pakan menjadi senyawa lebih sederhana sehingga kandungan SK pada perlakuan T1 menjadi lebih tinggi dibandingkan dengan perlakuan lainnya.

Tillman et al. (1998) menyatakan bahwa SK merupakan bagian dari bahan organik yang mempengaruhi kecernaan pakan. Semakin tinggi SK pakan maka semakin rendah KcBOnya.

\section{SIMPULAN DAN SARAN}

\section{Simpulan}

Hasil penelitian menunjukkan bahwa lama fermentasi berpengaruh nyata terhadap peningkatan kandungan protein kasar dan peneurunan serat kasar, akan tetapi tetapi waktu pemeraman dari 7 sampai dengan 28 hari tidak memberi peningkatan secara nyata terhadap kecernaan bahan kering dan bahan organik silase jerami jagung yang ditambah lamtoro dan molases.

\section{Saran}

Untuk mengetahui tingkat palatabilitas silase jerami jagung yang ditambah lamtoro dan molases, maka perlu dilakukan penelitian pada ternak ruminansia.

\section{DAFTAR PUSTAKA}

Amrin. 2014. Kandungan ADF dan NDF Jerami Padi yang Difermentasi dengan Kombinasi Kapur Tohor, Bacillus sp. dan Air Kelapa pada Waktu Yang Berbeda. Skripsi Fakultas Peternakan. Universitas Mataram.

Anggorodi, R. 1995. Nutrisi Aneka Ternak Unggas. PT. Gramedia. Jakarta. 
Fardiaz, S.1992. Mikrobiologi Pangan. PT. Gramedia Pustaka Utama, Jakarta.

Jafar, M. D. dan A. Hasan. 1990. Optimum Steaming Condition for Feed Utilization Processing and Utilization of Oil Palm by Products for Ruminant. MardiTarc Collaborative Study Malaysia.

Judoamidjojo, M., Said, dan L. Hartoto. 1989. Biokonversi. Pusat Antar Universitas. Bioteknologi. Institut Pertanian Bogor, Bogor.

Mathius, I. W. 1984. Hijauan gliricidia sebagai pakan ternak ruminansia. Wartazoa. Pusat penelitian dan pengembangan Peternakan Vol. 1 No. 4 pp. 19

McDonald, P. 1981. Biochemistry of Silage. JohnWiley and Sons, New York.

Oscar, Y., M. Iqbal, Dahlanuddin, S. H. Dilaga. 2016. Pengaruh Penambahan Lamtoro Terhadap Kualitas Jerami Jagung yang Dihasilkan. Laporan PNBP 2016 Universitas Mataram. Mataram.
Reksohadiprodjo, S. 1985. Produksi Biji Rumput dan Legum Makanan Ternak Tropik. BPFE UGM, Yogyakarta.

SAS. 2001. SAS/STAT User's Guide. Version 80, $1^{\text {th }}$ Ed. SAS Institute Inc. Cary.NC.USE.

Sukria, H. A. dan K. Rantan. 2009. Sumber dan Ketersediaan Bahan Pakan di Indonesia.IPB Press. Bogor.

Sutardi, T. 1980. Landasan Ilmu Nutrisi. Penerbit IPB Bogor, Bogor.

Steel, R.G.D. dan J.H. Torrie, 1989. Prinsip dan Prosedur Statistika. Suatu Pendekatan Biometrik. Terjemahan: Bambang Sumantri, Penerbit Jakarta. Jakarta.

Tillman, A.D., H.Hartadi, dan S. Reksodiprodjo. 1998. Tabel Komposisi Bahan Makanan Ternak Untuk Indonesia. Gadjah Mada University Press, Yogyakarta

Volk, W.A and M.F. Wheeler. 1993. Mikrobiologi Dasar. Edisi Ke lima. Jilid 1. Penerbit Erlangga. Jakarta. 